\title{
ECOPHYSIOLOGY OF WEST INDIAN CHERRY IRRIGATED WITH SALINE WATER UNDER PHOSPHORUS AND NITROGEN DOSES
}

\author{
ECOFISIOLOGIA DA ACEROLEIRA IRRIGADA COM ÁGUA SALINA SOB DOSES \\ DE FÓSFORO E NITROGENNIO
}

\begin{abstract}
Francisco Vanies da Silva SÁ ${ }^{1}$; Hans Raj GHEYI ${ }^{2}$; Geovani Soares de LIMA ${ }^{3}$; Emanoela Pereira de PAIVA ${ }^{4}$; Luderlândio de Andrade SILVA; Rômulo Carantino Lucena MOREIRA ${ }^{5}$; Pedro Dantas FERNANDES ${ }^{6}$; Adaan Sudário DIAS ${ }^{5}$

1. Doutor em Engenharia Agrícola, Pós-Doutorando em Manejo de Solo e Água PNPD/CAPES, UFERSA, Universidade Federal Rural do Semi-Árido - UFERSA, Mossoró-RN, Brasil, E-mail: vanies_agronomia@ @otmail.com; 2. Professor Visitante, Universidade Federal do Recôncavo da Bahia, Cruz das Almas, BA, Brasil; 3. Professor Visitante, Universidade Federal de Campina Grande - UFCG, Unidade Acadêmica de Ciências Agrárias, Pombal, PB, Brasil; 4. Pós-Doutorando em Fitotecnia, PNPD/CAPES, UFERSA, Mossoró-RN, Brasil; 5. Doutorando em Engenharia Agrícola, UFCG, Campina Grande, PB, Brasil; 6. Professor Visitante, UFCG, Campina Grande, PB, Brasil.
\end{abstract}

\begin{abstract}
The quantitative and qualitative scarcity of water resources is a frequent problem in the semi-arid region of the Brazilian Northeast. The availability of water for irrigation with high content of dissolved salts is common, affecting the growth and development of the crops. Thus, it is necessary to adopt strategies that allow the establishment of irrigated agriculture in this region. The objective of this study was to evaluate the effect of water salinity and phosphorus/nitrogen combinations on the ecophysiology of the West Indian cherry grafted in the first year of cultivation. The research was carried out in a protected environment, in lysimeters filled with a Regolithic Neosol of loamy clay texture, having low initial phosphorus content. The experiment was arranged in a randomized block design, arranged in a $5 \times 4$ factorial scheme, with five levels of electrical conductivity of the irrigation water - $\mathrm{ECw}\left(0.6,1.4,2.2,3.0\right.$ and $\left.3.8 \mathrm{dS} \mathrm{m}^{-1}\right)$ and four managements of fertilization with phosphorus and nitrogen $(100: 100 ; 140: 100 ; 100: 140$ and $140: 140 \% \mathrm{P} / \mathrm{N}$ of the recommendation), with three replications, each plot consisting of one plant. Increased salinity of irrigation water reduced growth, photosynthesis and the production of West Indian cherry. Fertilization with 140\% of recommendation of the phosphorus and nitrogen minimizes the deleterious effect of salinity on West Indian cherry irrigated with water up to $3.0 \mathrm{dS} \mathrm{m}^{-1}$.
\end{abstract}

KEYWORDS: Malphigia emarginata. Semi-arid region. Irrigation. Saline stress. Fertilization.

\section{INTRODUCTION}

Water availability in semi-arid regions is limited, especially in periods of higher atmospheric demand that coincide with periods of low rainfall. The Brazilian semi-arid region has small volume of river water flow, due to the temporal variability of rainfalls and dominant geological features, which lead to a dense network of intermittent rivers, and few perennial rivers. Therefore, groundwater is a promising alternative, but most of it has excess of salts dissolved (AYERS; WESTCOT, 1985; MEDEIROS, 1992).

In this region, water salinity is a problem as worrisome as low rainfall, and it is necessary to understand its causes and develop technologies for crop management and/or recovery of halomorphic soils (MEDEIROS, 1992; SÁ et al., 2017). Saline waters used in irrigation may pose risk to agricultural production, causing alterations of either osmotic or ionic nature in the development of most crops (MUNNS; TESTER, 2008; HABIBI; AMIRI, 2013). Besides osmotic and ionic effects, nutritional imbalance is caused by the alterations in the processes of absorption, transport, assimilation and distribution of nutrients in the plant, e.g., the excess of $\mathrm{Na}^{+}$and $\mathrm{Cl}^{-}$inhibits the absorption of ions such as $\mathrm{K}^{+}, \mathrm{Ca}^{2+}, \mathrm{Mg}^{2+}, \mathrm{NO}_{3}^{-}$and $\mathrm{H}_{2} \mathrm{PO}_{4}^{-}$, negatively influencing plant growth, physiology and production (SYVERTSEN; GARCIA-SANCHEZ, 2014; RIBEIRO et al., 2016; SÁ et al., 2017).

Among the strategies used to mitigate the effects of saline stress on crops, adequate fertilization management has stood out due to the positive responses, especially using phosphorus and nitrogen (LIMA et al., 2015; SÁ et al., 2017). This fact occurs because these nutrients are essential for plants, in metabolic and structural functions, including in photosynthesis, a vital mechanism for plant survival. In addition, adequate supply of these nutrients in plants under saline stress conditions may influence the osmotic adjustment (amino acids 
and sugars) and energy storage (ASHRAF; HARRIS, 2004; TAIZ et al., 2015). Nevertheless, studies on the joint action of these two nutrients in plants under saline stress are scarce in the literature.

West Indian cherry (Malphigia emarginata DC.) is a plant of tropical climate native to northern South America, Central America and Caribbean Islands. It stands out for the high content of ascorbic

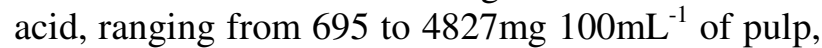
high yield and rusticity, which promotes good adaptation to regions of semi-arid climate (MEZADRI et al., 2008; CALGARO; BRAGA, 2012). The cultivated area in Brazil is estimated at about 10,000 ha, with major participation of the states of Pernambuco, Bahia, Ceará, Paraíba, Rio Grande do Norte and Piauí, which together hold $64 \%$ of the national production, denoting predominance of the commercial cultivation (fresh, processed) of this species in the semi-arid region (CALGARO; BRAGA, 2012; ESASHIKA et al., 2013).

Given the above, this study aimed to evaluate the effect of water salinity and phosphorus/nitrogen combinations on the ecophysiology of grafted West Indian cherry in the first year of cultivation.

\section{MATERIAL AND METHODS}

The experiment was carried out in a greenhouse at the Center of Technology and Natural Resources (CTRN) of the Federal University of Campina Grande (UFCG), located in the municipality of Campina Grande, Paraíba, PB,
Brazil, at geographic coordinates $7^{\circ} 15^{\prime} 18^{\prime}, \mathrm{S}$, $35^{\circ} 52^{\prime} 28^{\prime}, \mathrm{W}$ and at mean altitude of $550 \mathrm{~m}$.

The experiment was installed in randomized blocks, in a 5 x 4 factorial arrangement, corresponding to five levels of irrigation water electrical conductivity $(0.6 ; 1.4 ; 2.2 ; 3.0$ and $3.8 \mathrm{dS}$ $\mathrm{m}^{-1}$ ) and four fertilization managements based on variations in the recommended proportions of phosphorus/nitrogen (P/N) (100:100; 140:100; 100:140 and 140:140\% P/N), with three replicates and one plant per plot. The recommendation corresponding to $100 \% \mathrm{~N}$ fertilization (23.85 g of $\mathrm{N}$ plant year ${ }^{-1}$ ) and $100 \% \mathrm{P}$ fertilization (45.0 $\mathrm{g}$ of $\mathrm{P}_{2} \mathrm{O}_{5}$ plant year ${ }^{-1}$ ) was based on Musser (1995).

The experiment was installed in lysimeters with capacity for $250 \mathrm{dm}^{3}$, which had a nonwoven geotextile $\left(\right.$ Bidim $^{\circledR}$ ) at the bottom under a $5-\mathrm{cm}$ thick layer of crushed stone $n^{\circ} 1$. The soil used to fill the lysimeters was classified as Regolithic Neosol with clay loam texture (0-30 cm layer), from the municipality of Esperança, PB, and its physical and chemical attributes (Table 1) were determined according to methodologies proposed by Donagema et al. (2011).

Solutions with lowest levels of electrical conductivity (ECw of 0.6 and $1.4 \mathrm{dS} \mathrm{m}^{-1}$ ) were prepared by diluting public-supply water $(\mathrm{ECW}=$ $1.78 \mathrm{dS} \mathrm{m}^{-1}$ ) in rainwater (ECw: $0.02 \mathrm{dS} \mathrm{m}^{-1}$ ), whereas the other solutions (ECw of 2.2, 3.0 and 3.8 $\mathrm{dS} \mathrm{m}{ }^{-1}$ ) were prepared by adding $\mathrm{NaCl}, \mathrm{CaCl}_{2} \cdot 2 \mathrm{H}_{2} \mathrm{O}$ and $\mathrm{MgSO}_{4} \cdot 7 \mathrm{H}_{2} \mathrm{O}$ salts to public-supply water, at equivalent proportion of $7: 2: 1$ respectively, which represents the average composition of ions present in waters used for irrigation in the semi-arid region of Northeast Brazil (MEDEIROS, 1992).

Table 1. Chemical and physical characteristics of the soil used in the experiment

\begin{tabular}{|c|c|c|c|c|c|c|c|c|c|}
\hline \multicolumn{10}{|c|}{ Chemical Characteristics } \\
\hline $\mathrm{pH}$ & $\mathrm{OM}$ & $\mathrm{P}$ & $\mathrm{K}^{+}$ & $\mathrm{Na}^{+}$ & $\mathrm{Ca}^{2+}$ & $\mathrm{Mg}^{2+}$ & $\mathrm{H}^{+}+\mathrm{Al}^{3+}$ & ESP & ECse \\
\hline $\begin{array}{l}\mathrm{H}_{2} \mathrm{O} \\
1: 2.5 \\
\end{array}$ & dag $k^{-1} g$ & $\mathrm{mg} \mathrm{kg}^{-1}$ & \multicolumn{5}{|c|}{ ( } & $\%$ & $\mathrm{dS} \mathrm{m}^{-1}$ \\
\hline 5.63 & 1.830 & 18.20 & 0.21 & 0.17 & 3.49 & 2.99 & 5.81 & 1.34 & 0.61 \\
\hline \multicolumn{10}{|c|}{ Physical characteristics } \\
\hline \multicolumn{3}{|c|}{$\begin{array}{l}\text { Granulometric fraction } \\
\qquad \mathrm{g} \mathrm{kg}^{-1}\end{array}$} & \multirow{2}{*}{$\begin{array}{l}\text { Textural } \\
\text { class }\end{array}$} & \multicolumn{2}{|c|}{ Water content $(\mathrm{kPa})$} & AW & $\begin{array}{l}\text { Total } \\
\text { Porosity }\end{array}$ & Ds & $\mathrm{Dp}$ \\
\hline Sand & Silt & Clay & & $\begin{array}{c}33.42 \\
\text { dag kg } \\
\end{array}$ & $\begin{array}{r}1519.5 \\
\text { dag kg-1 }\end{array}$ & dag $\mathrm{kg}^{-1}$ & $\mathrm{~m}^{3} \mathrm{~m}^{-3}$ & $---(\mathrm{kq}$ & $\left(m^{-3}\right)---$ \\
\hline 573 & 101 & 326 & CL & 12.68 & 4.98 & 7.70 & 0.5735 & 1.13 & 2.65 \\
\hline
\end{tabular}

$\mathrm{OM}$ - Organic matter: Walkley-Black Wet Digestion; $\mathrm{Ca}^{2+}$ and $\mathrm{Mg}^{2+}$ extracted with $1 \mathrm{~mol} \mathrm{~L}^{-1} \mathrm{KCl}$ at $\mathrm{pH} 7.0$; $\mathrm{Na}^{+}$and $\mathrm{K}^{+}$extracted using $1 \mathrm{~mol} \mathrm{~L}{ }^{-1} \mathrm{NH}_{4} \mathrm{OAc}$ at $\mathrm{pH} 7.0 ; \mathrm{H}^{+}$and $\mathrm{Al}^{3+}$ extracted using $0.5 \mathrm{~mol} \mathrm{~L}-1$ calcium acetate at $\mathrm{pH} 7.0$; ESP- Percentage of exchangeable sodium; CL- Clay loam; AW - Available water; Ds- soil density; Dp- Particle density; ECse - electrical conductivity of the soil saturation extract

Irrigations using solutions with the respective $\mathrm{ECW}$ levels were preestablished and performed every 3 days, replacing the evapotranspiration volume so as to increase soil 
moisture close to the maximum water retention capacity $(33.42 \mathrm{kPa})$. The volume applied in each irrigation was determined according to plant water needs based on water balance in the root zone, obtained by the difference between the applied volume and the volume drained in the previous irrigation. To avoid excessive accumulation of salts in the root zone, every 50 days the soil received a leaching fraction equivalent to 0.10 of the volume applied in the period (AYERS; WESTCOT, 1985).

Fertilizations with $\mathrm{N}$ and $\mathrm{P}$ were performed according to the preestablished treatments, using urea $(45 \% \mathrm{~N})$ as source of $\mathrm{N}$ and single superphosphate $\left(18 \% \mathrm{P}_{2} \mathrm{O}_{5}, 18 \% \mathrm{Ca}^{2+}, 12 \% \mathrm{~S}\right)$ as source of $\mathrm{P}$, based on the recommendation of Musser (1995). In addition, $19.8 \mathrm{~g}$ of $\mathrm{K}_{2} \mathrm{O}$ was applied per plant in the form of potassium chloride $\left(60 \% \mathrm{~K}_{2} \mathrm{O}\right)$. In the fertilizations, 250 and $350 \mathrm{~g}$ of superphosphate were applied before planting in the treatments of 100 and $140 \% \mathrm{P}$ recommendation, respectively. Nitrogen fertilization was split into 24 equal portions, applied at 15-day intervals along the year, using $2.21 \mathrm{~g}$ of urea per plant in the $100 \%$ treatment and $3.09 \mathrm{~g}$ of urea per plant in the $140 \%$ treatment. Potassium fertilization was split into 12 portions, monthly applied at dose of $2.75 \mathrm{~g}$ of $\mathrm{KCl}$ per plant. Fertilization management $(\mathrm{N}$ and $\mathrm{P})$ started as seedlings were transplanted to the lysimeters. Pests, diseases and weeds were controlled as needed. From the beginning of flowering, plants began to receive weekly fertilizations with micronutrients at dose of $0.5 \mathrm{~g} \mathrm{~L}^{-1}$ using the foliar fertilizer Quimifol Nutri, which comprises $25 \%$ potassium $\left(\mathrm{K}_{2} \mathrm{O}\right), 2.5 \%$ magnesium, $6.0 \%$ sulfur, $2.0 \%$ boron, $0.5 \%$ copper, $0.3 \%$ molybdenum and $5.0 \%$ zinc.

To analyze the absolute (AGR) and relative (RGR) growth of West Indian cherry plants, rootstock and scion diameters were measured along the period from $1\left(\mathrm{t}_{1}\right)$ to $285\left(\mathrm{t}_{2}\right)$ days after applying the salinity levels (DASL). Rootstock stem diameter (mm) was measured $2 \mathrm{~cm}$ above the soil, while scion stem diameter was measured $2 \mathrm{~cm}$ above the grafting point. Absolute (AGR) and relative (RGR) growth rates of West Indian cherry were determined using Eqs.1 and 2, respectively (BENINCASA, 2003).

$$
\begin{aligned}
& A G R=\frac{A 2-A 1}{t 2-t 1} \\
& R G R=\frac{\ln A 2-\ln A 1}{t 2-t 1}
\end{aligned}
$$

where: $\mathrm{A}_{2}$ - studied variable, measured at the end of the period, $\mathrm{mm} ; \mathrm{A}_{1}$ - studied variable, measured at the beginning of the period, $\mathrm{mm} ; \mathrm{t}_{2}-\mathrm{t}_{1}$ - time difference between measurements, days; and, ln natural logarithm.

Gas exchanges were measured at 285 days after applying the salinity levels, using the portable photosynthesis meter LCPro+ (ADC BioScientific Ltd.), operating with control of temperature at 25 ${ }^{\circ} \mathrm{C}$, irradiation of $1200 \mu \mathrm{mol}$ photons $\mathrm{m}^{-2} \mathrm{~s}^{-1}$ and air flow of $200 \mathrm{~mL} \mathrm{~min}^{-1}$, and at $\mathrm{CO}_{2}$ level of the environment, in leaves at $3 \mathrm{~m}$ height from soil surface, obtaining the following variables: $\mathrm{CO}_{2}$ assimilation rate $-A\left(\mu \mathrm{mol} \mathrm{m}{ }^{-2} \mathrm{~s}^{-1}\right)$, transpiration - $E$ $\left(\mathrm{mol} \mathrm{H} \mathrm{H}_{2} \mathrm{O} \mathrm{m}^{-2} \mathrm{~s}^{-1}\right)$, stomatal conductance - $g s$ (mol $\mathrm{H}_{2} \mathrm{O} \mathrm{m}^{-2} \mathrm{~s}^{-1}$ ) and internal $\mathrm{CO}_{2}$ concentration - $\mathrm{Ci}$ $\left(\mu \mathrm{mol} \mathrm{m} \mathrm{m}^{-2} \mathrm{~s}^{-1}\right)$ in the third leaf from the apex. These data were used to quantify the instantaneous water use efficiency - WUEi $(\mathrm{A} / \mathrm{T})\left[\left(\mu \mathrm{mol} \mathrm{m} \mathrm{m}^{-2}\right)(\mathrm{mol}\right.$ $\left.\left.\mathrm{H}_{2} \mathrm{O} \quad \mathrm{m}^{-2} \mathrm{~s}^{-1}\right)^{-1}\right]$ and instantaneous carboxylation efficiency - A/Ci (EiCi) (SILVA et al., 2014).

In the same period, chlorophyll $a$ fluorescence was determined using a modulated pulse fluorometer (model OS5p - Opti Science). Firstly, the Fv/Fm protocol was used to determine initial fluorescence (Fo), maximum fluorescence $(\mathrm{Fm})$, variable fluorescence $(\mathrm{Fv}=\mathrm{Fm}-\mathrm{Fo})$ and maximum quantum efficiency of photosystem II (Fv/Fm) (SÂ et al., 2017). This protocol was carried out after dark adaptation of leaves for a 30-min period, using a clip of the device, to guarantee that all acceptors were oxidized, i.e., with open reaction centers.

In the determination of West Indian cherry water status, three fully expanded leaves were collected from the middle third of each plant to determine the relative water content (RWC) in the leaf blade and leaf water saturation deficit (WSD). For that, fresh weight (FW) was determined immediately after leaves were collected. Then, the leaf samples were placed in plastic bags, immersed in distilled water and stored for 24 hours. After this period, excess water was removed with a paper towel, to obtain the turgid weight (TW), and the samples were taken to the oven (temperature $\approx 65$ ${ }^{\circ} \mathrm{C} \pm 3{ }^{\circ} \mathrm{C}$, until constant weight) to obtain the dry weight (DW). RWC and WSD were determined based on the methodology described by Lima et al. (2015), using Eq. 3 and 4:

$$
\begin{aligned}
& R W C=\frac{F W-D W}{T W-D W} \times 100 \\
& W S D=\frac{T W-F W}{T W-D W} \times 100
\end{aligned}
$$

Where: $\mathrm{RWC}=$ relative water content $(\%)$; $\mathrm{WSD}=$ water saturation deficit (\%); FW= leaf fresh weight $(\mathrm{g}) ; \mathrm{TW}=$ turgid weight $(\mathrm{g}) ; \mathrm{DW}=$ dry weight $(\mathrm{g})$. 
West Indian cherry production during the first year of cultivation was evaluated based on the number of fruits per plant, obtained by counting all fruits harvested per plant; Average fruit weight, by calculating the mean weight of all fruits harvested per plant; fruit longitudinal and transverse diameters, in mm, measured using a digital caliper respectively from apex to base and along the equatorial region of all fruits harvested.

The data were subjected to analysis of variance by $\mathrm{F}$ test and, in case of significance of the isolated factors, means relative to $\mathrm{P} / \mathrm{N}$ proportions were compared by Tukey test $(\mathrm{p}<0.05)$ and means relative to irrigation water salinity levels were compared by regression. In case of significant interaction $(\mathrm{p}<0.05)$, a follow-up regression analysis was carried out for $\mathrm{P} / \mathrm{N}$ proportions in each salinity level, using the program Sisvar version 5.1 (FERREIRA, 2011).
SÁ, F. V. S. et al.

\section{RESULTS AND DISCUSSION}

There was significant effect $(\mathrm{p}<0.05)$ of the interaction between water salinity and fertilization managements on the number of fruits per plant (Table 2).

Absolute growth rates in diameter of rootstock (AGR-DRS) and scion (AGR-DS), relative growth rates in diameter of rootstock (RGRDRS) and scion (RGR-DS), $\mathrm{CO}_{2}$ assimilation rate $(A)$, instantaneous carboxylation efficiency ( $\mathrm{EiCi})$, stomatal conductance $(g s)$, transpiration $(E)$, instantaneous water use efficiency (WUEi), maximum fluorescence (Fm) and variable fluorescence (Fv), Average fruit weight (AFW) and longitudinal diameter (FLD) responded to the isolated effects $(\mathrm{p}<0.05)$ of irrigation water salinity (Table 2).

Table 2. Summary of $\mathrm{F}$ test for absolute growth rates in diameter of rootstock (AGR-DRS) and scion (AGRDS), relative growth rates in diameter of rootstock (RGR-DRS) and scion (RGR-DS) from 1 to 285 days, relative water content (RWC), water saturation deficit (WSD), $\mathrm{CO}_{2}$ assimilation rate $(A)$, internal $\mathrm{CO}_{2}$ concentration $(\mathrm{Ci})$, instantaneous carboxylation efficiency $(\mathrm{EiCi})$, stomatal conductance $(g s)$, transpiration $(E)$, instantaneous water use efficiency (WUEi), initial fluorescence (Fo), maximum fluorescence $(\mathrm{Fm})$, variable fluorescence $(\mathrm{Fv})$, quantum efficiency of photosystem II $(\mathrm{Fv} / \mathrm{Fm})$, number of fruits per plant (NFP), Average fruit weight (AFW), fruit longitudinal diameter (FLD) and fruit transverse diameter (FTD) in West Indian cherry irrigated with saline water and fertilized with phosphorus/nitrogen proportions in the first year of cultivation.

\begin{tabular}{|c|c|c|c|c|c|c|c|c|}
\hline \multirow[b]{2}{*}{ SV } & \multirow[b]{2}{*}{ DF } & \multicolumn{7}{|c|}{ Significance of ' $F$ ' test } \\
\hline & & $\begin{array}{l}\text { AGR- } \\
\text { DRS }\end{array}$ & $\begin{array}{l}\text { AGR- } \\
\text { DS }\end{array}$ & $\begin{array}{l}\text { RGR- } \\
\text { DRS }\end{array}$ & $\begin{array}{l}\text { RGR- } \\
\text { DS }\end{array}$ & RWC & WSD & A \\
\hline Block & 2 & $*$ & ns & ns & ns & ns & ns & $*$ \\
\hline Salt & 4 & $*$ & $*$ & $*$ & $*$ & ns & ns & $*$ \\
\hline $\mathrm{P} \mathrm{P} / \mathrm{N}$ & 3 & $\mathrm{~ns}$ & $\mathrm{~ns}$ & $\mathrm{~ns}$ & $\mathrm{~ns}$ & ns & ns & ns \\
\hline Salt x P P/N & 12 & ns & ns & ns & ns & ns & ns & ns \\
\hline $\mathrm{CV}(\%)$ & & 19.83 & 14.56 & 23.85 & 17.71 & 4.37 & 28.85 & 27.13 \\
\hline \multirow{2}{*}{ SV } & \multirow{2}{*}{ DF } & \multicolumn{7}{|c|}{ Significance of ' $F$ ' test } \\
\hline & & $\mathrm{Ci}$ & $\mathrm{EiCi}$ & gs & $\mathrm{E}$ & WUEi & Fo & Fm \\
\hline Block & 2 & $*$ & ns & $*$ & $*$ & $*$ & ns & $*$ \\
\hline Salt & 4 & ns & $*$ & $*$ & $*$ & $*$ & ns & $*$ \\
\hline P P/N & 3 & ns & ns & ns & ns & ns & ns & ns \\
\hline Salt x P P/N & 12 & ns & ns & ns & ns & ns & ns & ns \\
\hline $\mathrm{CV}(\%)$ & & 17.49 & 31.29 & 34.32 & 26.28 & 25.53 & 12.16 & 10.90 \\
\hline \multirow{2}{*}{ SV } & \multirow{2}{*}{ DF } & \multicolumn{7}{|c|}{ Significance of ' $F$ ' test } \\
\hline & & Fv & $\mathrm{Fv} / \mathrm{Fm}$ & & & & FDL & FDT \\
\hline Block & 2 & ns & ns & & & & ns & ns \\
\hline Salt & 4 & $*$ & ns & & & & $*$ & ns \\
\hline $\mathrm{P} \mathrm{P} / \mathrm{N}$ & 3 & ns & ns & & & & ns & ns \\
\hline Salt x P P/N & 12 & ns & ns & & & & ns & ns \\
\hline CV $(\%)$ & & 16.55 & 7.65 & & & & 6.44 & 7.01 \\
\hline
\end{tabular}

*Significant at 0.05 probability level; ns - Not significant; SV - Source of variation; DF - Degrees of freedom; Salt - Salinity levels; $\mathrm{P}$ P/N - Proportion of P/N fertilization; CV - Coefficient of variation 
Relative water content (RWC), water saturation deficit (WSD), internal $\mathrm{CO}_{2}$ concentration (Ci), initial fluorescence (Fo) and quantum efficiency of photosystem II $(\mathrm{Fv} / \mathrm{Fm})$ were not significantly influenced $(p>0.05)$ by the studied factors (Table 2).

Increasing irrigation water salinity reduced the growth in diameter of West Indian cherry rootstock and scion, and there were reductions of 8.35, 4.82, 9.55 and $6.23 \%$ in AGR-DRS, RGRDRS, AGR-DS and RGR-DS, respectively, per unit increase in irrigation water electrical conductivity (Figures 1A, B, C and D). The inhibition of growth in West Indian cherry rootstock and scion diameters is related to the accumulation of salts in the root zone, added by the successive irrigations with saline water. In addition, the excess of salts in the root zone intensifies the osmotic stress, increasing the

A.

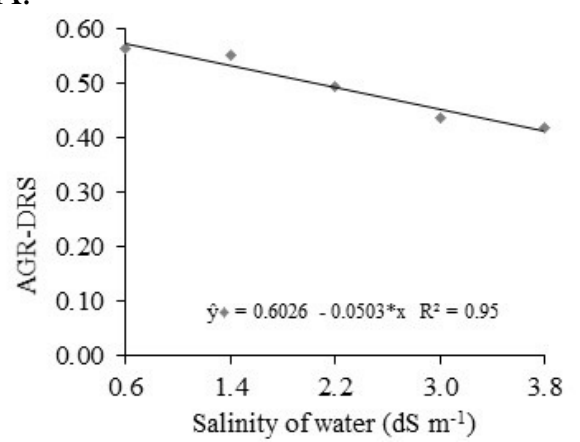

C.

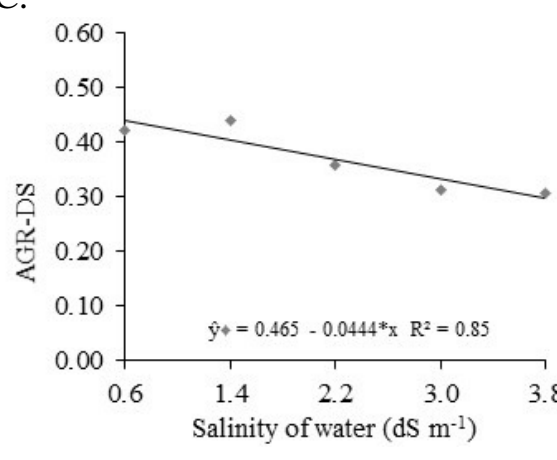

energy expenditure to absorb water and, moreover, some salts when absorbed in excess cause toxicity, triggering a series of physiological disorders, such as reduction in photosynthesis, limiting plant growth and development (MUNNS; TESTER, 2008; SYVERTSEN; GARCIA-SANCHEZ, 2014).

Evaluating the growth of West Indian cherry seedlings after grafting subjected to saline water irrigation, Gurgel et al. (2007) observed linear reductions in all growth variables as a function of the increase in water salinity. In the seedling stage, these authors found a $2.39 \%$ reduction in seedling stem diameter 50 days after grafting per unit increase in salinity level, while in the present study the reductions in growth rates were more than $4 \%$, indicating that the deleterious effect of water salinity on plants occurs due to the time of exposure to the saline environment.

B.

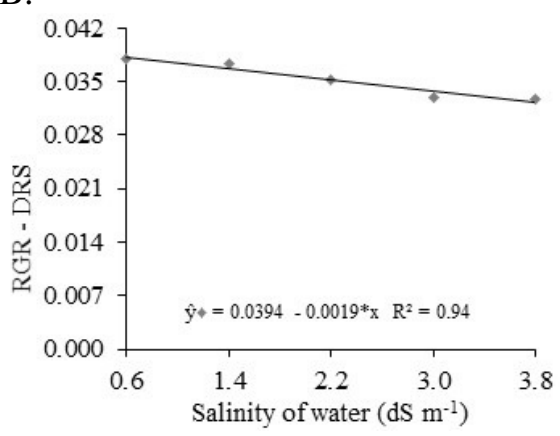

D.

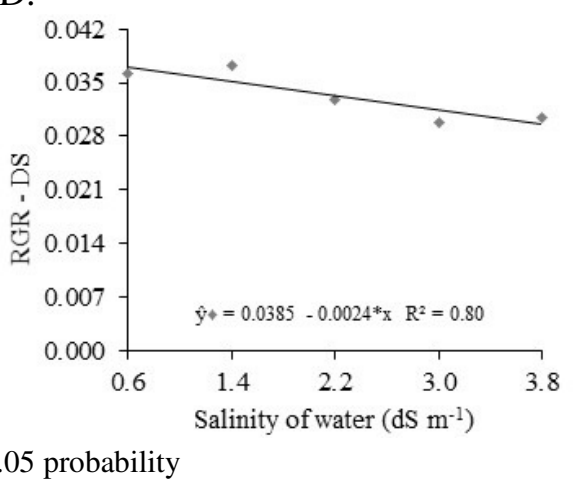

Figure 1. Absolute growth rate $\left(\mathrm{AGR}-\mathrm{mm} \mathrm{day}^{-1}\right)$ and relative growth rate (RGR - mm mm $\mathrm{may}^{-1}$ ) in diameter of rootstock - DRS (A and B) and scion - DS (C and D) from 1 to 185 days in West Indian cherry plants under saline water irrigation and fertilization managements with phosphorus/nitrogen proportions, at 285 days after applying the salinity levels.

Growth reductions caused by osmotic and ionic effects as a function of saline water irrigation were also found by Brito et al. (2014), evaluating citrus genotypes subjected to saline stress in the rootstock and post-grafting stages. These authors observed that there was a progressive effect of saline stress along the time of rootstock exposure to the stress, a situation that resulted in greater growth reductions in grafted seedlings according to the tolerance of the rootstock. In a brief comparison, it is possible to note that, even in the seedling stage, some citrus scion/rootstock combinations, the most sensitive to the stress, obtained greater reductions of growth in diameter per unit increase in salinity, compared with those found in the present study for West Indian cherry plants in the first year of cultivation. Thus, it is possible to infer that the West 
Indian cherry scion/rootstock combination has good performance under saline stress conditions.

It is important to point out that scion diameter was more compromised by the increase in water salinity than rootstock diameter, and this is related to the higher rusticity and also to the tolerance mechanism of the species, which is able to send higher concentrations of organic solutes to the

A.

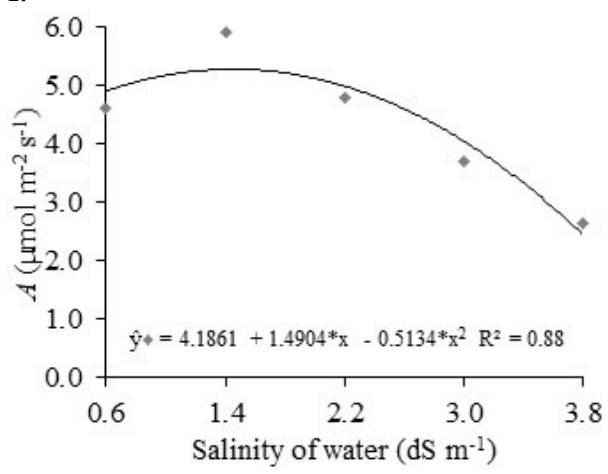

C.

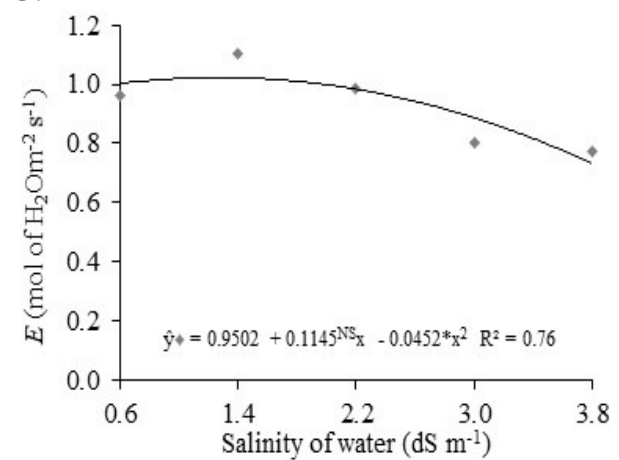

roots (rootstock) and, thus, tolerate adverse conditions imposed by the osmotic stress, by regulating root water potential. In addition, a greater supply of organic solutes, consequently higher availability of energy, enables the plant to increase its selectivity in the absorption and exclusion of ions, favoring ionic homeostasis (GUPTA; HUAG, 2014).

B.

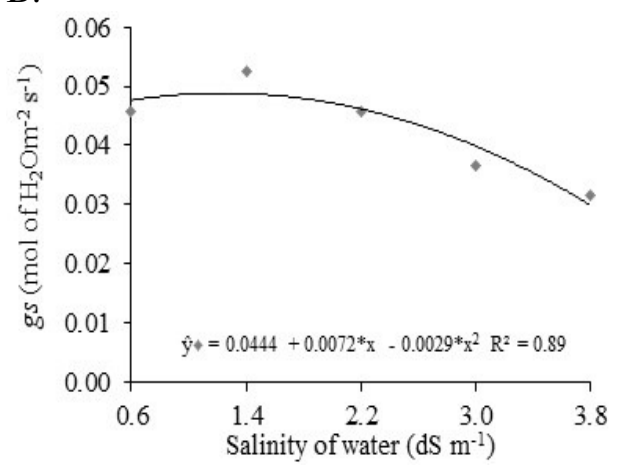

D.

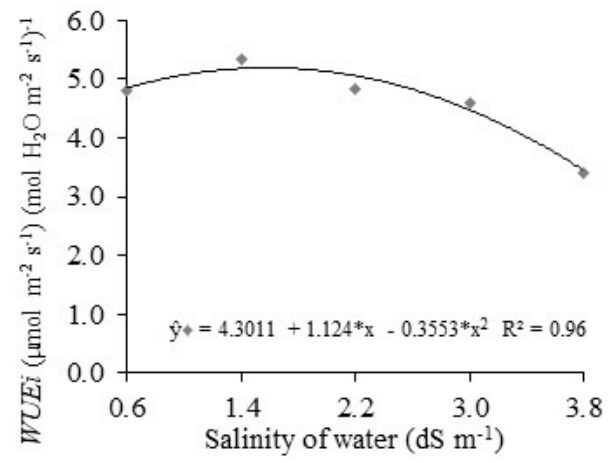

E.

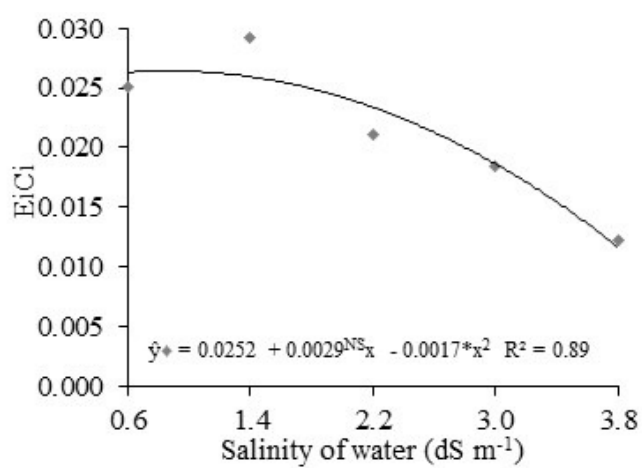

$*$ and ${ }^{\mathrm{NS}}=$ Significant to 0.05 probability and not significant, respectively

Figure 2. $\mathrm{CO}_{2}$ assimilation rate - $A(\mathrm{~A})$, stomatal conductance - $g s(\mathrm{~B})$, transpiration - $E(\mathrm{C})$, instantaneous water use efficiency - WUEi (D) and instantaneous carboxylation efficiency - EiCi (E) of grafted West Indian cherry under saline water irrigation and fertilization managements with phosphorus/nitrogen proportions, at 285 days after applying the salinity levels.

West Indian cherry gas exchange variables fitted to a quadratic regression model as a function of the increase in irrigation water salinity, with increments in $\mathrm{CO}_{2}$ assimilation rate, stomatal conductance, transpiration, instantaneous carboxylation efficiency and instantaneous water use efficiency up to salinity levels of $1.45,1.24$, $1.27,1.58$ and $0.85 \mathrm{dS} \mathrm{m}^{-1}$, respectively. From these $\mathrm{ECw}$ levels on, all variables decreased and the lowest values were obtained at $3.8 \mathrm{dS} \mathrm{m}^{-1}$ (Figures $1 \mathrm{~A}, \mathrm{~B}, \mathrm{C}, \mathrm{D}$ and $\mathrm{E})$. Based on these results, it is possible to identify a salinity threshold of $2.2 \mathrm{dS} \mathrm{m}^{-1}$ 
for the gas exchanges of West Indian cherry plants, except $\mathrm{EiCi}$, because the values were similar to those of plants in the control treatment $\left(0.6 \mathrm{dS} \mathrm{m}^{-1}\right)$.

Reduction in stomatal activity is one of the main effects caused by saline stress on plants, which acts by limiting water loss through transpiration, as observed in the present study (Figure 2B and C). Transpiration promotes variations in the water potential of cell walls, intercellular spaces and xylem, allowing for potential difference, which favors the absorption of water and nutrients again through the root system (TAIZ et al., 2015; XU et al., 2015). Consequently, increase or reduction in transpiration rate acts as a mechanism to regulate cell water potential and can be used by the plant to withstand abiotic stress conditions (HABIBI; AMIRI, 2013; GARRIGA et al., 2014; DADKHAH, 2015). Such tolerance mechanism is of great importance when used under saline stress conditions, enabling the plant to overcome osmotic stress and/or reduce the absorption of water and toxic ions dissolved.

This mechanism probably allows the plant to regulate its water status, as observed in West Indian cherry, because no influence of saline stress was observed on the relative water content and

A.

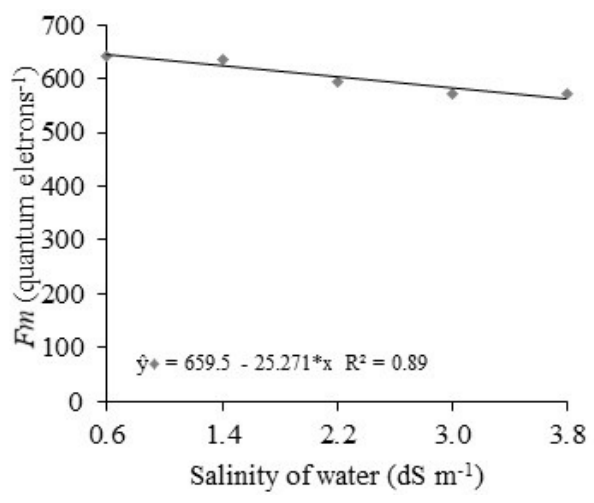

SÁ, F. V. S. et al.

water saturation deficit in the leaves. Nevertheless, the reduction in stomatal activity and transpiration rate was not efficient to increase the instantaneous water use efficiency in West Indian cherry plants under saline conditions (Figure 2D). This occurred due to the reduction in $\mathrm{CO}_{2}$ assimilation rate, which may be attributed to factors of non-stomatal nature, since stomatal closure did not influence the internal $\mathrm{CO}_{2}$ concentration and there was a negative influence of increased salinity on instantaneous carboxylation efficiency, confirming that biochemical alterations such as reduction in energy supply and reducing power, influencing the activity of the enzyme Ribulose-1,5-bisphosphate carboxylase/oxygenase (RuBisCO), hampering the photosynthetic activity of West Indian cherry plants (HUSSAIN et al., 2012; SILVA et al., 2014).

The reduction in $\mathrm{CO}_{2}$ assimilation rate may be related to the decline in maximum fluorescence and variable fluorescence of chlorophyll $a$, influenced by the increase in irrigation water salinity, because maximum fluorescence and variable fluorescence of chlorophyll $a$ decreased by 12.55 and $18.82 \%$ between the highest $\left(3.8 \mathrm{dS} \mathrm{m}^{-1}\right)$ and lowest $\left(0.6 \mathrm{dS} \mathrm{m}^{-1}\right)$ salinity levels, respectively (Figures $3 \mathrm{~A}$ and $\mathrm{B}$ ).

B.

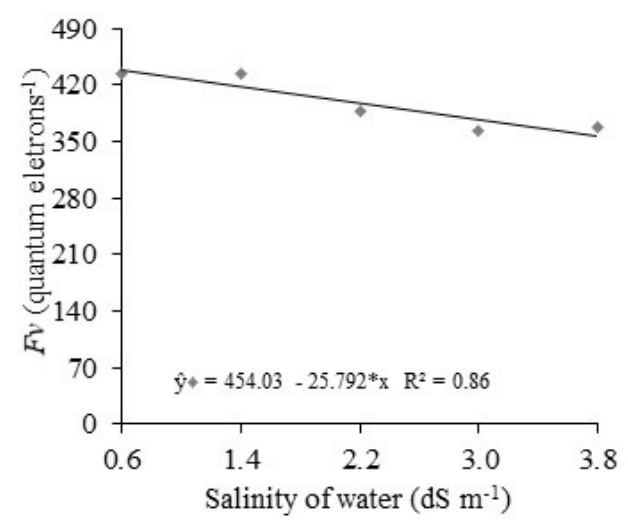

$*$ = Significant at 0.05 probability

Figure 3. Maximum fluorescence - Fm (A) and variable fluorescence - Fv (B) of West Indian cherry plants under saline water irrigation and fertilization managements with phosphorus/nitrogen proportions, at 285 days after applying the salinity levels.

Maximum fluorescence (Fm) refers to the state in which the PSII reaction centers reached maximum capacity, evidencing the reduced condition of all the quinone (QA) by the electrons transferred from P680, and its intensity is determinant in the variable fluorescence, which is the potentially active energy in PSII (BAKER; ROSENQVST, 2004; SILVA et al., 2014). Reduction in Fm and Fv is an indication of decrease in chlorophyll $a$ activity and, consequently, decrease in generation of energy and reducing power, such as Adenosine Triphosphate (ATP) and Nicotinamide adenine dinucleotide phosphate (NADP), which are essential for the proper functioning of RuBisCO in the $\mathrm{CO}_{2}$ carboxylation process (HUSSAIN et al., 2012; TAIZ et al., 2015; DABROWSKI et al., 2017).

Although there was no influence of the treatments on the quantum efficiency of PS II $(\mathrm{Fv} / \mathrm{Fm})$, the reduction in chlorophyll $a$ activity, or 
the energy loss in PSII of $9.41 \%$ (Fv), observed at salinity levels above $2.2 \mathrm{dS} \mathrm{m}^{-1}$ in comparison to the control treatment $\left(0.6 \mathrm{dS} \mathrm{m}^{-1}\right)$, led to reduction in photosynthetic activity, which eventually affect the growth of West Indian cherry plants (Figures 1A, B, C, D, 2A and B).

Regarding West Indian cherry production, the interaction between salinity levels and fertilization managements had effect on fruit production (Table 2). In plants fertilized with the recommended amounts of $\mathrm{P}$ and $\mathrm{N}$ (M1 = 100:100\% $\mathrm{P} / \mathrm{N}$ ) and in those under increased $\mathrm{N}$ fertilization $(\mathrm{M} 3=100: 140 \% \mathrm{P} / \mathrm{N})$, fruit production was reduced by water salinity and decreased by 21.54 and $15.65 \%$ per unit increase in irrigation water electrical conductivity, respectively (Figure 4A). On the other hand, in plants under exclusive increase of phosphate fertilization $(\mathrm{M} 2=140: 100 \% \mathrm{P} / \mathrm{N})$ and increase in both fertilizations (M4 $=140: 140 \%$ $\mathrm{P} / \mathrm{N}), \mathrm{P} / \mathrm{N}$ proportions caused a quadratic effect on fruit production. Highest values of NFP (82.93 and

A.

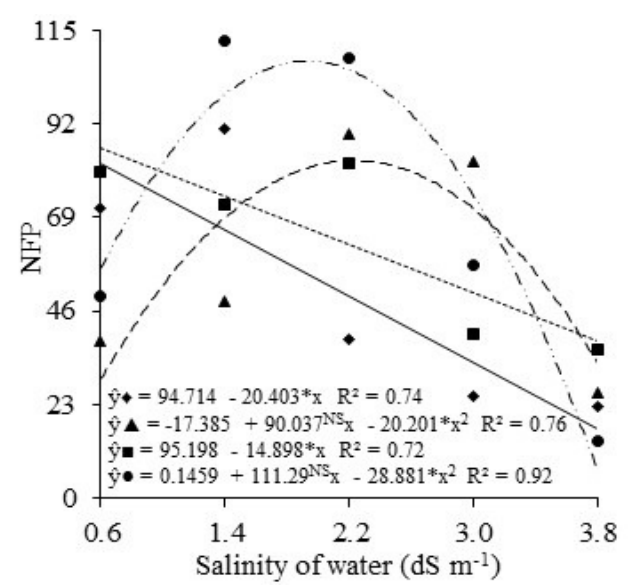

C.

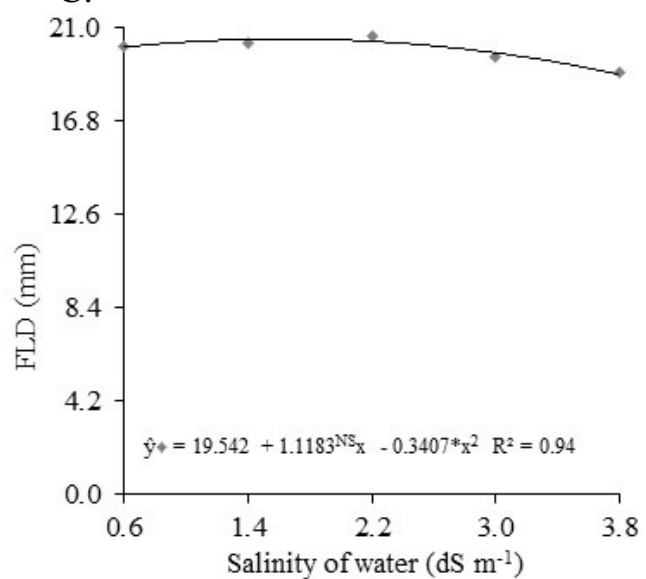

$\bullet \mathrm{M} 1-100: 100 \% \mathrm{P} / \mathrm{N} ; \boldsymbol{\Delta} \mathrm{M} 2-140: 100 \% \mathrm{P} / \mathrm{N} ; \mathbf{m} 3-100: 140 \% \mathrm{P} / \mathrm{N}$ and $\bullet \mathrm{M} 4-140: 140 \% \mathrm{P} / \mathrm{N}$

$*$ and ${ }^{\mathrm{NS}}=$ Significant at 0.05 probability and not significant, respectively

Figure 4. Number of fruits per plant - NFP (A), Average fruit weight - AFW (B) and fruit longitudinal diameter - FLD (C) in West Indian cherry plants under saline water irrigation and fertilization managements with phosphorus/nitrogen proportions, at 365 days after applying the salinity levels.
107.37 fruits/plant) were found at estimated salinity levels of 2.23 and $1.93 \mathrm{dS} \mathrm{m}^{-1}$, respectively (Figure $4 \mathrm{~A})$.

The increment in production at moderate levels of salinity was probably due to the greater availability of calcium and magnesium in the soil, and also to the stimulus caused by the reduction in the osmotic potential (induced water stress), causing the plants to change faster from the vegetative to the reproductive stage (flowering/fruiting). Associated with phosphate fertilization, which increases plant production precocity (RAIJ, 1991), it led to higher fruit production in West Indian cherry plants. However, it is important to point out that the joint increase in $\mathrm{N}$ and $\mathrm{P}$ doses caused higher production compared with treatments with exclusive increment in $\mathrm{N}$ and $\mathrm{P}$. Thus, it can be stated that there is a synergetic action between $\mathrm{P}$ and $\mathrm{N}$ on West Indian cherry production, so that $\mathrm{P}$ intensifies the effects of $\mathrm{N}$ fertilization on West Indian cherry plants grown under saline stress.

B.

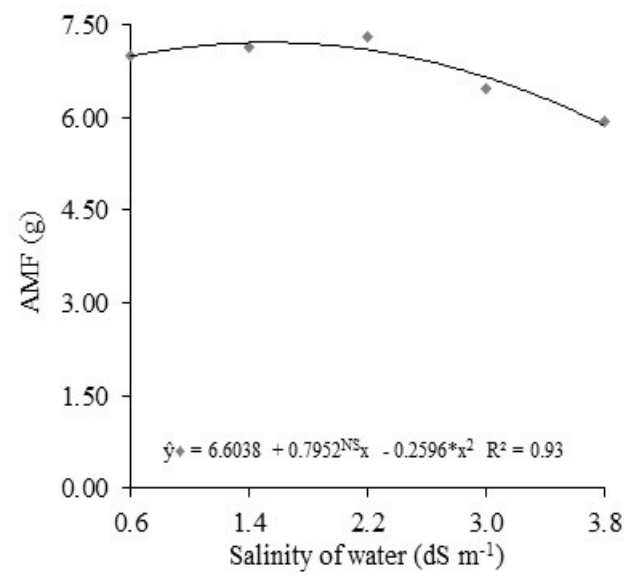


Average fruit weight (AFW) and longitudinal diameter (FLD) of West Indian cherry fruits showed a quadratic behavior as a function of the increase in water salinity, with maximum values of $7.21 \mathrm{~g}$ and $20.46 \mathrm{~mm}$ respectively estimated at $\mathrm{ECw}$ levels of 1.53 and $1.64 \mathrm{dS} \mathrm{m}^{-1}$. After these levels, MFW and FLD decreased and the reductions were more expressive at salinity levels above $3.0 \mathrm{dS}$ $\mathrm{m}^{-1}$ (Figures 4B and C). Under conditions of high salinity, West Indian cherry plants had reductions in not only fruit production, but also in fruit weight and size, as a function of the saline stress. In addition, there was no significant effect of water salinity on fruit transverse diameter (Table 2), indicating that the reductions in fruit weight are related to the reduction in the longitudinal diameter. However, even with the reductions in the weight and size of West Indian cherry fruits, the results obtained in the present study for the cultivar BRS366-Jaburu up to the salinity level of $3.0 \mathrm{dS} \mathrm{m}^{-1}$ were higher than those of five out of six West Indian cherry accessions studied by Lima et al. (2014), regarding fruit biometry, thus indicating that irrigations with water salinity of $3.0 \mathrm{dS} \mathrm{m}^{-1}$ do not affect the biometric characteristics of West Indian cherry fruits.

\section{CONCLUSIONS}

Increase in water salinity reduces West Indian cherry growth, photosynthetic activity and production, and plants can be irrigated with water salinity of up to $2.2 \mathrm{dS} \mathrm{m}^{-1}$, expecting small losses of growth and production. There is synergetic action between phosphorus and nitrogen in mitigating the effects of saline stress on West Indian cherry production, up to the salinity of $3.0 \mathrm{dS} \mathrm{m} \mathrm{m}^{-1}$. Fertilization with $140 \%$ of the recommendation of phosphorus and nitrogen minimizes the deleterious effect of salinity on the production of West Indian cherry irrigated using water of up to $3.0 \mathrm{dS} \mathrm{m}^{-1}$.

\section{ACKNOWLEDGEMENTS}

$\mathrm{CNPq}$ and Capes for grant of scholarships and the INCTSal for financial support.

RESUMO: A escassez quantitativa e qualitativa dos recursos hídricos é um problema frequente na região semiárida do Nordeste brasileiro, sendo comum a disponibilidade de água para irrigação com elevados teores de sais, afetando o crescimento e o desenvolvimento das culturas. Assim é necessário adoção de estratégias que viabilize o estabelecimento de cultivo irrigado nessa região. Com isso, objetivou-se com este trabalho avaliar o efeito da salinidade de água e manejos da combinação fósforo/nitrogênio sobre a ecofisiologia da acerola enxertada no primeiro ano de cultivo. A pesquisa foi realizada em ambiente protegido, em lisímetros preenchidos com Neossolo Regolítico de textura franco-argilosa, possuindo baixo teor inicial de fósforo. $\mathrm{O}$ experimento foi instalado em delineamento de blocos casualizados, arranjados em esquema fatorial $5 \times 4$, sendo cinco níveis de condutividade elétrica da água de irrigação - CEa $\left(0,6 ; 1,4 ; 2,2 ; 3,0\right.$ e 3,8 dS m m $\left.^{-1}\right)$ e quatro manejos de adubação com fósforo e nitrogênio (100:100; 140:100; 100:140 e 140:140\% da recomendação de $\mathrm{P} / \mathrm{N}$ ), com três repetições, sendo cada parcela constituída de uma planta. $\mathrm{O}$ aumento da salinidade da água de irrigação reduziu o crescimento, a fotossíntese e a produção da aceroleira. Adubação com $140 \%$ da recomendação de fósforo e nitrogênio minimiza o efeito deletério da salinidade sobre a produção de aceroleira irrigada com água de até $3,0 \mathrm{dS} \mathrm{m}^{-1}$.

PALAVRAS-CHAVE: Malphigia emarginata. Região semiárida. Irrigação. Estresse salino. Adubação.

\section{REFERENCES}

ASHRAF, M.; HARRIS, P. J. C. Potential biochemical indicators of salinity tolerance in plants. Plant Science, London, v. 166, n. 1, p. 3-16, jan. 2004. https://doi.org/10.1016/j.plantsci.2003.10.024

AYERS, R. S.; WESTCOT, D. W. Water quality for agriculture. Rome: Food and Agriculture Organization of the United Nations. 1985. 174p.

BAKER, N. R.; ROSENQVIST, E. Aplication of chlorophyll fluorescence can improve crop production strategies: An examination of future possibilities. Journal of Experimental Botany, Oxford, v. 55, n. 443, p. 1607-1621, jul. 2004. https://doi.org/10.1093/jxb/erh196 
BENINCASA, M. M. P. Análise de crescimento de plantas: Noções básicas. Jaboticabal: FUNEP, 2003. 41p.

BRITO, M. E. B.; BRITO, K. S. A. DE; FERNANDES, P. D.; GHEYI, H. R.; SUASSUNA, J. F.; SOARES FILHO, W. dos S.; MELO, A. S. de; XAVIER, D. A. Growth of ungrafted and grafted citrus rootstocks under saline water irrigation. African Journal of Agricultural Research, Lagos, v. 9, n. 50, p. 3600-3609, dez. 2014. https://doi.org/10.5897/2014.9039

CALGARO, M.; BRAGA, M. B. A cultura da acerola. 3. ed. rev. ampl. - Brasília, DF : Embrapa, 2012, 150p.

DĄBROWSKI, P.; KALAJI, M. H.; BACZEWSKA, A. H.; PAWLUŚKIEWICZ, B.; MASTALERCZUK, G.; BORAWSKA-JARMUŁOWICZ, B.; PAUNOV, M.; GOLTSEV, V. Delayed chlorophylla fluorescence, MR820, and gas exchange changes in perennial ryegrass under salt stress. Journal of Luminescence, New York, v.183, n. 3, p. 322-333, mar. 2017. https://doi.org/10.1016/j.jlumin.2016.11.031

DADKHAH, A. Effect of long term salt stress on gas exchange and leaf carbohydrate contents in two sugar beet (Beta vulgaris L.) cultivars. Russian Agricultural Sciences, Moscow, v. 41, n. 6, p. 423-428, jun. 2015.

DONAGEMA, G. K.; CAMPOS, D. V. B.; CALDERANO, S. B.; TEXEIRA, W. G.; VIANA, J. H. M. Manual de métodos de análise de solo. 2. ed. Rio de Janeiro, RJ: Embrapa Solos, 2011. 230p.

ESASHIKA, T.; OLIVEIRA, L. A. de; MOREIRA, F. W. Resposta da aceroleira a adubação orgânica, química e foliar num Latossolo da Amazônia Central. Revista de Ciências Agrárias, Lisboa, v. 36, n. 2, p. 399-410, mai./ago. 2013.

FERREIRA, D. F. Sisvar: A computer statistical analysis system. Ciência e Agrotecnologia, v. 35, n. 6, p. 1039-1042, jul. 2011. http://dx.doi.org/10.1590/S1413-70542011000600001.

GARRIGA, M.; RETAMALES, J. B.; BRAVO, S. R.; CALIGARI, P. D. S.; LOBOS, G. A. Chlorophyll, anthocyanin, and gas exchange changes assessed by spectroradiometry in Fragaria chiloensis under salt stress. Journal of Integrative Plant Biology, v. 56, n. 5, p. 505-515, mai. 2014. http://dx.doi.org/10.1111/jipb.12193.

GUPTA, B.; HUANG, B. Mechanism of salinity tolerance in plants: physiological, biochemical, and molecular characterization. International Journal of Genomics, New York, v.2014, n. 1, p.1-18, jan. 2014. http://dx.doi.org/10.1155/2014/701596

GURGEL, M. T.; FERNANDES, P. D.; GHEYI, H. R.; SANTOS, F. J. S.; BEZERRA, I. L. Uso de águas salinas na produção de mudas enxertadas de aceroleira. Revista Caatinga, Mossoró, v. 20, n. 1, p. 16-23, jan./mar. 2007.

HABIBI, F.; AMIRI, M. E. Influence of in vitro salinity on growth, mineral uptake and physiological responses of two citrus rootstocks. International Journal of Agronomy and Plant Production, London, v.4, n. 6, p.1320-1326, jul. 2013.

LIMA, G. S.; GHEYI, H. R.; NOBRE, R. G.; SOARES, L. A. A.; XAVIER, D. A.; SANTOS JUNIOR, J. A. Water relations and gas exchange in castor bean irrigated with saline water of distinct cationic nature. African Journal of Agricultural Research, Lagos, v.10, n. 13, p.1581-1594, mar. 2015.

http://dx.doi.org/10.5897/AJAR2015.9606

LIMA, P. C. C.; SOUZA, B. S.; SOUZA, P. S.; BORGES, S. S.; ASSIS, M. D. O. Caracterização e avaliação de frutos de aceroleira. Revista Brasileira de Fruticultura, Jaboticabal, v. 36, n. 3, p. 550-555, jul./set. 2014. http://dx.doi.org/10.1590/0100-2945-336/13. 
MEDEIROS, J. F. Qualidade da água de irrigação e evolução da salinidade nas propriedades assistidas pelo 'GAT' nos estados do RN, PB e CE. Campina Grande, Dissertação (Mestrado), 1992. 137p. Universidade Federal da Paraíba.

MEZADRI, T.; VILLAÑO, D.; FERNÁNDEZ-PACHÓN, M.; GARCÍA-PARRILLA, M.; TRONCOSO, A. M. Antioxidant compounds and antioxidantactivity in acerola (Malpighia emarginata DC.) fruits and derivatives. Journal of Food Composition and Analysis, Oxford, v. 21, n. 4, p. 282-290, jun. 2008. https://doi.org/10.1016/j.jfca.2008.02.002

MUNNS, R.; TESTER, M. Mechanism of salinity tolerance. Annual Review of Plant Biology, Palo Alto, v.59, n. 1, p.651-681, jan. 2008. https://doi.org/10.1146/annurev.arplant.59.032607.092911.

MUSSER, R. S. Tratos culturais na cultura da acerola. In: SÃO JOSÉ, A. R.; ALVES, R. E. (ed.). Acerola no Brasil: Produção e mercado. Vitória da Conquista: DFZ/UESB, 1995. Cap.3, p.47-52.

RAIJ, B. V. Fertilidade do solo e adubação. Piracicaba: Ceres/Potafos, 1991. 343 p.

RIBEIRO, P. H. P.; GHEYI, H. R.; UYEDA, C. A.; TEIXEIRA, M. B.; SOARES, F. A. L.; DIAS, N. S. Taxa de crescimento e produção de girassol irrigado com água salina sob doses de nitrogênio. Irriga, Botucatu, Ed. Esp., n. Grandes Culturas, p. 233-247, dez. 2016. http://dx.doi.org/10.15809/irriga.2016v1n1p233-247.

SÁ, F. V. da S.; BRITO, M. E. B.; SILVA, L. de A.; MOREIRA, R. C. L.; FERNANDES, P. D.;

FIGUEIREDO, L. C.; MELO, A. S.; PAIVA, E. P. Physiology and phytomass of saccharine sorghum (Sorghum bicolor) in saline-sodic soil treated with correctives and single superphosphate. Australian Journal of Crop Science, Lismore, v. 11, n. 10, p. 1290-1296, out. 2017.

http://dx.doi.org/10.21475/ajcs.17.11.10.pne592

SILVA, L. de A.; BRITO, M. E. B.; SÁ, F. V. da S.; MOREIRA, R. C. L. M.; SOARES FILHO, W. dos S.; FERNANDES, P. D. Mecanismos fisiológicos em híbridos de citros sob estresse salino em cultivo hidropônico. Revista Brasileira de Engenharia Agrícola e Ambiental, Campina Grande, v.18, n. suplementar, p.S1-S7, dez. 2014. http://dx.doi.org/10.1590/1807-1929/agriambi.v18nsupps1-s7.

SYVERTSEN, J. P.; GARCIA-SANCHEZ, F. Multiple abiotic stresses occurring with salinity stress in citrus. Environmental and Experimental Botany, Oxford, v.103, n. 4, p.128-137, jul. 2014. http://dx.doi.org/10.1016/j.envexpbot.2013.09.015.

TAIZ, L.; ZEIGER, E.; MØLLER, I. M.; MURPHY, A. Plant physiology and development. 6.ed., New York: Sinauer Associates, 2015.761p.

XU, X.; LI, Y.; WANG, B.; HU, J.; LIAO, Y. Salt stress induced sex-related spatial heterogeneity of gas exchange rates over the leaf surface in Populus cathayana Rehd. Acta Physiologie Plantarun, Heidelberg, v. 37, n. 1, p. 1709-1718, jan. 2015. 